\title{
Evidentiary powers of the trial court regarding public-law disputes in the Russian Federation
}

\author{
Evgeny Nikolaevich Kulyushin* \\ Ural State Law University (USLU), 620066, Yekaterinburg, Russia
}

\begin{abstract}
The paper presents the analysis of the content of the evidentiary powers of the trial court regarding public-law disputes in administrative proceedings of the Russian Federation to improve the model of their exercise by the general courts for correct and timely consideration and resolution of public-law disputes between citizens, organizations against unlawful acts of public bodies. It considers the key directions of improvement of the mechanism of evidentiary activity of courts on public-law disputes regarding the recognition of evidence inadmissible, procedure for allegations on falsification of evidence to ensure effective protection of the weaker party on public-law disputes, to create a good-faith attitude among the participants of public-law relations, and to prevent new public-law disputes. Taking into account the analysis of the content of the evidentiary powers of the trial court in public-law disputes, the paper concludes on the criteria for classifying the evidentiary powers of the trial court in public-law disputes under the Code of Administrative Procedure of the Russian Federation, active role of the trial court in their implementation at various stages of administrative proceedings, main directions for improving the mechanism for exercising the evidentiary powers of the trial court in verifying the allegations on falsification of evidence submitted by the parties and taking measures to declare the evidence inadmissible.
\end{abstract}

\section{Introduction}

Proper and timely consideration and resolution of public-law disputes between citizens, organizations (hereinafter - individuals) and public bodies is one of the tasks of administrative proceedings carried out by the general courts. Proper and timely consideration and resolution of public-law disputes is ensured through the powers of the trial court to form the evidentiary material. These powers received the name of the evidentiary powers of the court. A fair judgment, prevention of new public-law disputes, and establishment of a partnership in public-law relations between individuals and public-law bodies depend on the quality of the court's evidentiary powers.

The evidentiary powers exercised by the trial court are similar to those exercised in civil proceedings, as reflected in domestic [1] and foreign procedural doctrine [2].

The study discusses the content and classification of the powers of the court in public-law disputes, possible directions for improving the mechanism for the court's evidentiary powers.

\section{Materials and Methods}

In order to understand the content and classification of the evidentiary powers of the trial court in administrative proceedings of the Russian Federation, as well as recommendations for improving the model of evidentiary powers in administrative proceedings of the Russian Federation, the following sources were used:

1) legislation of Germany, France, England, the USA and Russia regulating the procedural activities of the trial court in public-law disputes;

2) scientific articles on the exercise of powers by the trial court in administrative proceedings;

3) judicial practice on the exercise of evidentiary powers in administrative proceedings.

The legislation of Germany, France, England, the USA and the Russian Federation have some similarities in the legal regulation of the evidentiary powers of the trial court [3] based on the principle of an objective investigation of all the circumstances of the case in order to protect the violated rights and legitimate interests of individuals against public authorities [4].

The domestic doctrine of civil and arbitration processes reflects the issues of inclusion, study, evaluation of evidence submitted by the parties in support of their claims and objections on the merits of the dispute, recognition of evidence as inadmissible [5], court's verification of allegations on falsification of evidence [6].

After the adoption of the Administrative Procedure Code in 2015 the studies on evidentiary presumptions in administrative proceedings, the implementation of the principle of the court's activity in public-law disputes,

Corresponding author: e.n.kulyushin@usla.ru 
measures to counter the falsification of evidence have become widespread [7].

The activity of the court in the exercise of its evidentiary powers is comprehensively considered in scientific articles [8].

The details of the evidentiary activities of the trial court in administrative proceedings were explained by the data of judicial practice in specific cases of court proceedings.

Some comparative legal, formal legal analyses of the texts of scientific articles on the implementation of evidentiary powers by the trial court, regulatory legal acts of Russian and foreign legislation, materials of judicial practice were used in order to draw conclusions on the essence, content, classification of the evidentiary powers of the trial court in administrative proceedings, the main directions of improving the mechanism for recognizing certain evidence as inadmissible, countering the parties in the inclusion of falsified evidence in the case.

\section{Content and classification of evidentiary powers of the court in public-law disputes}

The evidence of public-law disputes includes information on the facts to be established by the court for their correct and timely resolution, submitted as prescribed by law [9].

The content of the evidentiary powers of the trial court in administrative proceedings consists of procedural actions aimed at collecting, investigating and evaluating evidence in order to establish valid legal relations between the parties. All this is ensured through the necessary evidence examined during the trial.

The fundamental principle that reveals the content of the scope of the evidentiary powers of the court and the mechanism of its activities is the principle of the court's activity in considering and resolving public-law disputes (Paragraph 7, Article 6 of the Administrative Procedure Code of the Russian Federation).

Let us consider the main directions of the mechanism of the court's evidentiary powers in administrative proceedings and formulate criteria for their classification, and determine the main elements of evidentiary powers.

The evidentiary powers of the court include the definition of the fact at issue (Part 3, Article 62 of the Administrative Procedure Code of the Russian Federation), collection of evidence (Part 1, Article 63 of the Administrative Procedure Code of the Russian Federation), discovery of evidence suo motu (Parts 4, 6, Article 69 of the Administrative Procedure Code of the Russian Federation).

This list requires additions to include other powers exercised by the court at various stages of the process.

At the stage of case preparation for trial by the court, the following types of evidentiary powers are exercised, which should be classified according to the following criteria:

I. by the source of evidence

II. by the fact at issue

III. by the presence or absence of circumstances indicating the need for urgent trials in public-law disputes.

IV. by the need to apply provisional remedy in public-law disputes.

The content of the evidentiary powers of the court by the source of evidence is manifested in the proceedings in respect of the following:

- parties to a case;

- related parties;

- witnesses;

- specialists;

- experts;

- reception of written and material evidence;

- commissioning of expert evidence.

These powers are exercised through the following measures:

- involvement, interrogation, consideration and resolution of allegations of the above subjects;

- adoption of the order for discovery of evidence from persons holding the evidence called for by the court or issue official requests for its discovery;

- adoption of the order for a court's request to obtain evidence;

- ensuring mandatory participation of persons in case in administrative proceedings.

We believe that the power of the court to ensure obligatory participation in relation to related parties, witnesses, specialists, experts should be supplemented.

Besides, the court should be given the power to ensure the timely disclosure of evidence by the parties to a case and to set a time frame for their disclosure taking into account the legal regulation of the institution of evidence disclosure in common law countries. Therefore, we believe that the proposals of Fokina M.A. on the need to establish a deadline for the disclosure of evidence by the parties to a case within 14 days are justified [10]. To ensure the possibility of fixing evidence in public-law disputes, the court should be empowered to provide evidence, since the lack of a procedure for providing evidence in the Administrative Procedure Code of the Russian Federation is its major drawback [11].

The power of the court in relation to the fact at issue to a case includes the establishment of circumstances that go beyond the basis of the asserted claims in the following cases:

1) on challenging normative legal acts, acts with normative properties;

2) on the protection of electoral rights and the right to participate in the referendum.

We consider it necessary to supplement the list of powers of the trial court to withdraw from the basis of the asserted claims in relation to any category of cases of public-law disputes taking into account the socially oriented model of administrative proceedings aimed at ensuring the protection of individuals against unlawful acts of public bodies.

In order to improve the model of evidentiary powers, the court should be given the power to terminate proceedings to a case in the absence of a violation of the subjective right of the administrative plaintiff. The court will have the power to discontinue proceedings both at the stage of preparation for proceedings and at the stage of proceedings on public-law disputes.

Consequently, the activity of the court in the exercise 
of evidentiary powers includes the adoption of measures to discover evidence suo motu (Part 2, Article 14, Part 1, Article 63, etc.). Failure to adopt these measures by the court in the consideration and settlement of public-law disputes is a ground for reversal of judicial decisions, as confirmed by judicial practice [12].

Thus, the specificity of the evidentiary powers of the court in public-law disputes is manifested in the preferential application of the permissive method of regulation by the court in contrast to the similar powers of the court in civil proceedings with the preferential method of permissibility.

\section{Content of the court power to verify allegations on the falsification of evidence, recognition of evidence as inadmissible}

The content of the evidentiary powers of the court in considering and resolving public-law disputes includes the commissioning of expert evidence suo motu in connection with the revealed circumstances in the case and the introduced evidence (Part 2, Article 77 of the Administrative Procedure Code of the Russian Federation). The court is not limited in the exercise of the powers to commission an expert evidence suo motu. The fact that the court has not commissioned the expert evidence suo motu is the basis for the reversal of the court decisions, which is confirmed by judicial practice [13].

The most common case for the commissioning of expert evidence is the verification of the allegation on falsification of evidence by the court.

In the domestic procedural doctrine, falsification of evidence is the actus reus misrepresentation of information about facts to be established in court or to provide information about facts that do not actually occur [14]. In order to prevent the use of such evidence, the court shall exercise the power to verify the falsification of evidence submitted by the parties and ensure its reliability. Chapter 6 of the Administrative Procedure Code of the Russian Federation - "Evidence and proof" does not contain rules governing the court's power to verify allegations on falsification of evidence. But in the procedural doctrine, when interpreting the provisions of Article 161 of the Arbitration Procedural Code of the Russian Federation, the following court powers were formulated when verifying the parties' allegations on falsification of evidence, which include:

- clarification of the criminal legal consequences of the allegation on falsification of evidence to the parties to a case;

- exclusion of the contested evidence from the evidence to a case with the consent of the person that submitted the evidence;

- verification of the validity of the allegation on falsification if the person that submitted the relevant evidence objects to its removal from the list of evidence [15].

The falsification of evidence in public-law disputes impedes the proper and timely consideration of cases pending before the court and undermines the authority of justice. In order to achieve the objective of administrative proceedings aimed at protecting the rights of citizens and organizations against unlawful acts of public bodies, the court should have the necessary and sufficient powers to ensure effective prevention, detection and suppression of falsification of judicial evidence.

A measure aimed at suppressing the falsification of judicial evidence is the power of the court to accept and send a private determination to the bodies of inquiry and preliminary investigation in the event that the court finds signs of a crime in the actions of participants in administrative proceedings when considering public-law disputes. Taking into account the statistics of the Judicial Department under the Supreme Court of the Russian Federation for 2018-2020, every six hundred people are convicted of falsifying evidence [16]. Therefore, it should be recognized that this measure of counteracting the falsification of evidence is not effective and requires further legislative regulation [17].

The measures of criminal liability for falsification of evidence are applied in foreign law and order [18].

The activity of the court to counter the falsification of evidence in the countries of the continental law system (France and Germany) and common law (England and the USA) is ensured by applying the combination of the court's powers to apply the following procedural sanctions:

1) court fine;

2) collection of legal expenses;

3) delictual liability;

4) professional liability of the representative of a party.

The use of a combination of these measures by courts in foreign law and order contributes to the prevention, timely detection and suppression of falsification of evidence in the administration of justice in public law disputes, since they are aimed at preventing unfair behavior of the parties when presenting evidence in the case to the court.

In addition to presenting documents to the court that do not contain reliable information in the case unfair conduct in considering public-law disputes are statements of unfounded requests to falsify evidence in the case.

The allegation of unfounded request is often aimed at delaying the time frame for the consideration of the case, causing harm to the other party by an unfounded accusation of falsification of evidence. One day of trial in the general courts in 2018 exceeded 25,000 rubles [19]. In this regard, we consider the proposal of Renz I.G. to apply punitive measures to parties claiming unfounded requests of falsification of evidence in order to prevent the delay in the consideration and resolution of public-law disputes, causing harm to the other party by unfounded accusation of falsification of evidence, reasonable [20]. When applying penalties to persons claiming unfounded requests for falsification of evidence, the court should take into account the purpose of this requests, which is aimed at causing harm to the other party, delaying the time frame for the consideration 
of the case, as well as the amount of fine that should be provided for in the Administrative Procedure Code of the Russian Federation. Therefore, the conclusions of the researchers on the improvement of measures aimed at bringing unscrupulous persons to justice should be considered correct, allowing the courts to classify these acts as the contempt of court [21].

The application of the penalty as a fine for persons making unreasonable requests should be reflected in the court's decision with the possibility of further appeal to a higher court for persons against whom the decision is made.

In addition to procedural sanctions, crossexamination is also carried out in order to detect and prevent the falsification of evidence in foreign law and order, which ensures the reliability of the witness's statement, obtaining the statement of the signatories of the original documents, and examination of the parties under oath [22].

Consequently, the active role of the court in administrative proceedings consists in the obligation to verify evidence that has not been withdrawn by the party contrary to the allegation on falsification.

At the same time, attention should be drawn to the exercise of the court's power to determine the admissibility or inadmissibility of evidence, since their exercise by the court provides the necessary guarantees for subsequent verification of the reliability of evidence [23].

Inadmissible evidence is evidence that cannot serve the basis for a court decision if it is received in violation of the provisions of the procedural law of the Russian Federation, the Convention for the Protection of Human Rights and Fundamental Freedoms and the Protocols thereto, the interpretation of the European Court of Human Rights. Such evidence is considered null and void [24].

Violations of procedural legislation in obtaining evidence are the use of threats, violence and other illegal actions, the use of methods in the course of proving contrary to modern scientific knowledge [25].

The court has the power to declare inadmissible evidence under the following:

- written motion of the party to a case;

- its own initiative (Part 2, Article 61 of the Administrative Procedure Code of the Russian Federation).

The exercise of the court's power to exclude inadmissible evidence obtained in violation of the law is a measure of state coercion (Part 3, Article 59 of the Administrative Procedure Code of the Russian Federation).

When the court establishes the unproven circumstances set forth in the petition of inadmissibility of evidence by the parties to a case, the court refuses to declare the evidence inadmissible (Part 3, Article 61 of the Administrative Procedure Code of the Russian Federation).

The domestic procedural doctrine draws attention to the insufficiency of the legal settlement of the procedure for excluding unacceptable evidence in the Administrative Procedure Code of the Russian
Federation.

There is a need to improve legal regulation taking into account the definition of the following:

- list of entities entitled to file a petition to exclude inadmissible evidence;

- process stages;

- form and content of a petition to exclude inadmissible evidence;

- process form of fixing court conclusions on the exclusion of inadmissible evidence;

- court's justification of the exclusion of evidence due to its inadmissibility, if the initiative to exclude evidence comes from the court.

In this regard, we support the existing proposals to improve the procedural mechanism of the court and suggest adding the following provisions:

1) Part 3, Article 61 of the Administrative Procedure Code of the Russian Federation in the following wording: "In case of exclusion of inadmissible evidence at the initiative of the court, the burden of proving the circumstances on which the conclusion of inadmissibility of evidence is based should be imposed on the court".

2) Paragraph 25 of the decision of the Plenum of the Supreme Court of the Russian Federation No. 36 of September 27, 2016 "On certain issues of the application by the courts of the Code of Administrative Procedure of the Russian Federation" in the following wording: "Within the meaning of Article 154 of the Criminal Code of the Russian Federation with regard to the question of the admissibility of evidence, a request for the exclusion of evidence from an administrative case due to its inadmissibility is resolved by the court after hearing the parties to a case, their representatives by making a decision, including a recorded decision" [26].

\section{Conclusion}

The analysis of the content of the evidentiary powers of the trial court in the administrative proceedings of the Russian Federation under the Administrative Procedure Code of the Russian Federation allows making the following conclusions. The evidentiary powers of the trial court in administrative proceedings are one of the directions of the principle of the court's activity in considering and resolving cases of public-law disputes [27].

The activity of the court is manifested at the stages of the case preparation for trial and consideration of the case on the merits in the exercise of the powers over the following:

1) fact at issue

This should include the power of the court to:

- obtain the necessary evidence and set a deadline for submission;

- go beyond the grounds and arguments, declared requirements of the administrative plaintiff in cases of challenging normative acts and acts with normative properties, protection of electoral rights and the right of citizens to participate in the referendum.

In order to improve the protection of the rights of individuals, the power of the court to go beyond the 
grounds and arguments should be extended to any category of cases of public-law disputes, since administrative proceedings are aimed at protecting the rights of the weaker party to the case and are considered a socially oriented model of the court.

2) source of evidence

The court's authority over the source of evidence includes proceedings initiated by the court in respect of the following evidence:

- testimony,

- written and material evidence,

- audio and video recordings,

- call for expert, specialist, translator.

- commissioning of expert evidence (Part 2, Article 77 of the Administrative Procedure Code of the Russian Federation).

3) establishing the presence or absence of circumstances for holding urgent court hearings

4) application of provisional remedy measures.

In order to improve the model of evidentiary powers, the court should be given the power to discontinue proceedings in the absence of a violation of the subjective public law of the administrative plaintiff at the stage of preparation of the case for trial and at the stage of consideration of the case on the merits.

There is a need to recognize the proposals of domestic procedural experts on the need to empower the court to:

1) ensure the timely disclosure of evidence by the parties to a case and set a deadline for their disclosure taking into account the legal regulation of the institution of evidence disclosure in common law countries. The period for disclosing evidence is 14 days.

2) apply a set of measures aimed at preventing falsification of judicial evidence in relation to:

- persons who have submitted to the court evidence that does not contain reliable information in the case,

- persons filing unfounded requests on falsification of evidence in the case and acting with the purpose of delaying the trial, causing harm to the other party by unfounded accusation of falsification of evidence.

It should be considered justified that the proposals formulated in the doctrine of procedural law to improve the mechanism of evidentiary powers of the court to declare the evidence inadmissible at the court's initiative in administrative proceedings and the need to adopt changes regarding the court's power to adopt a protocol or separate decision by the court to exclude evidence in public-law disputes in view of its inadmissibility.

Thus, the active role of the trial court in administrative proceedings under the Administrative Procedure Code of the Russian Federation in the exercise of evidentiary powers is manifested in relation to the fact at issue in the case, the source of evidence, the establishment of circumstances of urgent court hearings, the application of provisional remedy measures, verification of the statement of falsification of evidence, recognition of evidence inadmissible.

The study was carried out with the financial support of the Russian Foundation for Basic Research as part of the scientific project No. 19-311-90013.

\section{References}

1. An.-M. Din.-M. Dzumatov, Activity of the court in the course of proof in the conditions of competitiveness in civil legal proceedings, Siberian legal review, 2, 286-293 (2020)

2. R. G. Odgers, El surgimiento del judicial case management: una sintesis evolutiva del control judicial del proceso civil en Europa, Rev. estud. hist.-juríd., 41, 179-205 (2019)

3. J.S. Oster, The scope of judicial review in the German and U.S. administrative legal system, German Law Journal, 9(10), 1267-1297 (2008)

4. F. Hufen, Verwaltungsprozessrecht. 11 Auflage. (Verlag C. H. Beck. München, 2018) 644 p.

5. I.V. Reshetnikova, Reflecting on judicial proceedings: Selected (Statut, Moscow, 2019) 510 p.

6. N.V. Ershova, Legal consequences of the declaration of falsification of evidence in civil proceedings, Topical problems of Russian law, 5(42), 842-848 (2014)

7. V.P. Popov, Fundamentals of the methodology for investigating crimes related to the falsification of evidence in administrative cases, Bulletin of the University named after O.E. Kutafin (Moscow State University), 2, 177-183 (2021)

8. N.A. Bortnikova, Concept of the "limits of proof", SPS ConsultantPlus (2021)

9. I.V. Reshetnikova, M.A. Kulikova, E.A. Tsaregorodtseva, Reference on proof in administrative proceedings: $2^{\text {nd }}$ edition, revised and amended (Norma, INFRA-M, Moscow, 2020) 160 p.

10. M.A. Fokina, Evidentiary law in a civilistic process: unrealized possibilities, Bulletin of civil process, $\mathbf{1}$, 29-46 (2019)

11. E.A. Nakhova, Comparative legal analysis of norms on evidence and proof in civilistic and administrative proceedings of Russia, Laws of Russia: experience, analysis, practice, 5, 38-42 (2016)

12. Cassation decision of the Judicial Board for Administrative Cases of the Supreme Court of the Russian Federation No. 48-KA19-1 dated June 25, 2019

13. Cassation decision of the Judicial Board for Administrative Cases of the Supreme Court of the Russian Federation No. 55-KG16-9 dated September 29, 2016

14. P.S. Yani, Falsification of evidence in a civil case: qualification issues, Legality, 4, 34-39 (2020)

15. A. Konyaeva, Falsification of evidence: theory and practice, EJ-Lawyer, 48, 3 (2017)

16. Summary statistical information on the state of criminal record in Russia for 2018, 2019, 2020. Retrieved 
http://www.cdep.ru/index.php?id=79 (date of address: 27.05.2021);

17. A. Cherkashin, Combating falsifications of evidence in the arbitration process. Retrieved from: https://zakon.ru/blog/2019/10/17/borba_s falsifikaci yami_dokazatelstv $\mathrm{v}$ arbitrazhnom processe_prodo lzhenie (date of address: 21.05.2021);

18. V. Bergmann, German Civil Procedure Code (Infotropik Media, Moscow, 2016) 388 p.

19. Momotov Judicial Reform of 2018 in the Russian Federation: concept, goals, content (Part II), Journal of Russian Law, 12, 68-89 (2019)

20. I.G. Renz, Liability for an unscrupulous statement about falsification of evidence, or why it is impossible to feed the bear with carrots. Retrieved from:

https://zakon.ru/blog/2018/04/13/otvetstvennost_za_ nedobrosovestnoe_zayavlenie_o_falsifikacii_dokaza telstv_ili_pochemu_ne_stoit_korm (date of address: 23.05.2021);

21. M.A. Bolovnev, Effectiveness of countering abuses of procedural rights: candidate dissertation (Omsk, 2018) $234 \mathrm{p}$.
22. S.F. Afanasyev, On the right to lie in the civilistic process and ways of leveling it (including taking into account electronic technologies), Lawyer, 1, 2228 (2020)

23. N.V. Ershova, Verification of the reliability of the statement on falsification of evidence in civil proceedings: candidate dissertation (Moscow, 2014) $206 \mathrm{p}$.

24. E.A. Nakhova, Parties, applicants as subjects of evidentiary activity in civilistic and administrative proceedings of the Russian Federation, Leningrad Legal Journal, 2, 224-232 (2016)

25. Concept of a single Civil Procedure Code of the Russian Federation. Preface be P.V. Krasheninnikova (Moscow, 2015) 224 p.

26. M.A. Fokina, Evidentiary law in a civilistic process: unrealized possibilities, Bulletin of civil process, $\mathbf{1}$, 29-46 (2019)

27. Th. Würtenberger, Dirk Heckman Verwaltungsprozessrecht: Ein Studienbuch (Verlag C. H. Beck. München, 2018) 366 p. 